\title{
Optimization of Organic-Containing Wastewater and Sludge Treatment Systems
}

\author{
V. I. Pyndak ${ }^{\dagger}$, A. E. Novikov*, and V. N. Shtepa \\ Volgograd State Agricultural University, Volgograd, Russia \\ *e-mail: novikov_al@mail.ru \\ Received August 8, 2016
}

\begin{abstract}
An enzymatic-cavitation method for the biological treatment of organic-containing wastewater and sludge treatment has been developed, according to which the air supply is carried out not by compressors, but rather ejectors. In addition, low-intensity cavitation is provided. The biological treatment of the wastewater has been performed at a temperature of $10-42^{\circ} \mathrm{C}$. The energy consumption of the process is reduced by six times, while the time of sludge treatment is $8-10 \mathrm{~h}$ at a pressure of $0.30-0.35 \mathrm{MPa}$. The treated sludge has some adsorptive properties.
\end{abstract}

DOI: $10.3103 / \mathrm{S} 1052618817040148$

Technical equipment for treating different types of wastewater and resulting sludge is available in any city and at some certain facilities. There is a tendency for creating small self-contained plants to treat the wastewater in places of their generation. However, the requirements in the equipment for treatment of the human-being and animal waste products are not met.

Existing treatment stations are based mainly on aerobic or anaerobic principles of biological impact on the organic components of the incoming wastewater; they occupy large areas, are characterized by high energy consumption, and are ecologically exceptionable. The main electric energy consumer is compressor facilities (air blowers) for compressed air or overheated steam suppliers [1-3]. An aerobic enzymaticcavitation method for the biological treatment of he organic-containing wastewater and sludge treatment has been developed [4-7]. The method was tested in the development of plants with carrying capacities of up to $10000 \mathrm{~m}^{3}$ per day. There are no compressors in the plants; the compressed air is supplied for free by ejectors. Here, the commercial pumps on the suction line have accessories that generate the cavitation a very low frequency with a cavitation number of $c_{\delta}=0.02-0.05$ (in regular pumps $c_{\delta}=4-6$ ).

The wastewater and sludge treatment is accompanied by the supply to the bioreactors and pumping out of the substrate saturated with the cavitation microcavities; here, compressed air is also supplied, where oxygen is a working body.

At the same time, during the process of the aerobic decomposition of the organic substance, the process of removing nitrogen compounds occurs, which is present in the wastewater in the form of ammonium ions $\mathrm{NH}_{4}^{+}$. The nitrification process is finally expressed by the equation $\mathrm{NH}_{4}^{+}+2 \mathrm{O}_{2} \rightarrow$ $\mathrm{NO}_{3}^{-}+\mathrm{H}_{2} \mathrm{O}+2 \mathrm{H}^{+}$, i.e., the reaction takes place under the action of oxygen, which is eight to ten times greater than commercial technologies (due to the operation of ejectors without any energy consumption).

Under the action of $\mathrm{NO}_{3}^{-}$, organics that are conditionally expressed by the symbol $\mathrm{CH}_{3} \mathrm{OH}$ continue to decompose.

A peculiarity of the structural design of the developed plants is the vertical (tower-shaped) structure of the bioreactors; their height achieves $10-12 \mathrm{~m}$. As a result, the area under the plant is reduced by four to five times, and the reactors can be supplied in the form of units of a high operational readiness. The principle diagram of the wastewater and sludge treatment (Fig. 1) shows that its main components are the articles of traditional machine-building, i.e., tubular casings, pumps, ejectors, filters, centrifuges, pipeline systems, etc.

As is known [2], the microcavity (microbubble) medium is favorable for the development and life activity of the microorganisms, including enzymes that break the molecules of the organic substances, and

\footnotetext{
$\dagger$ Deceased.
} 


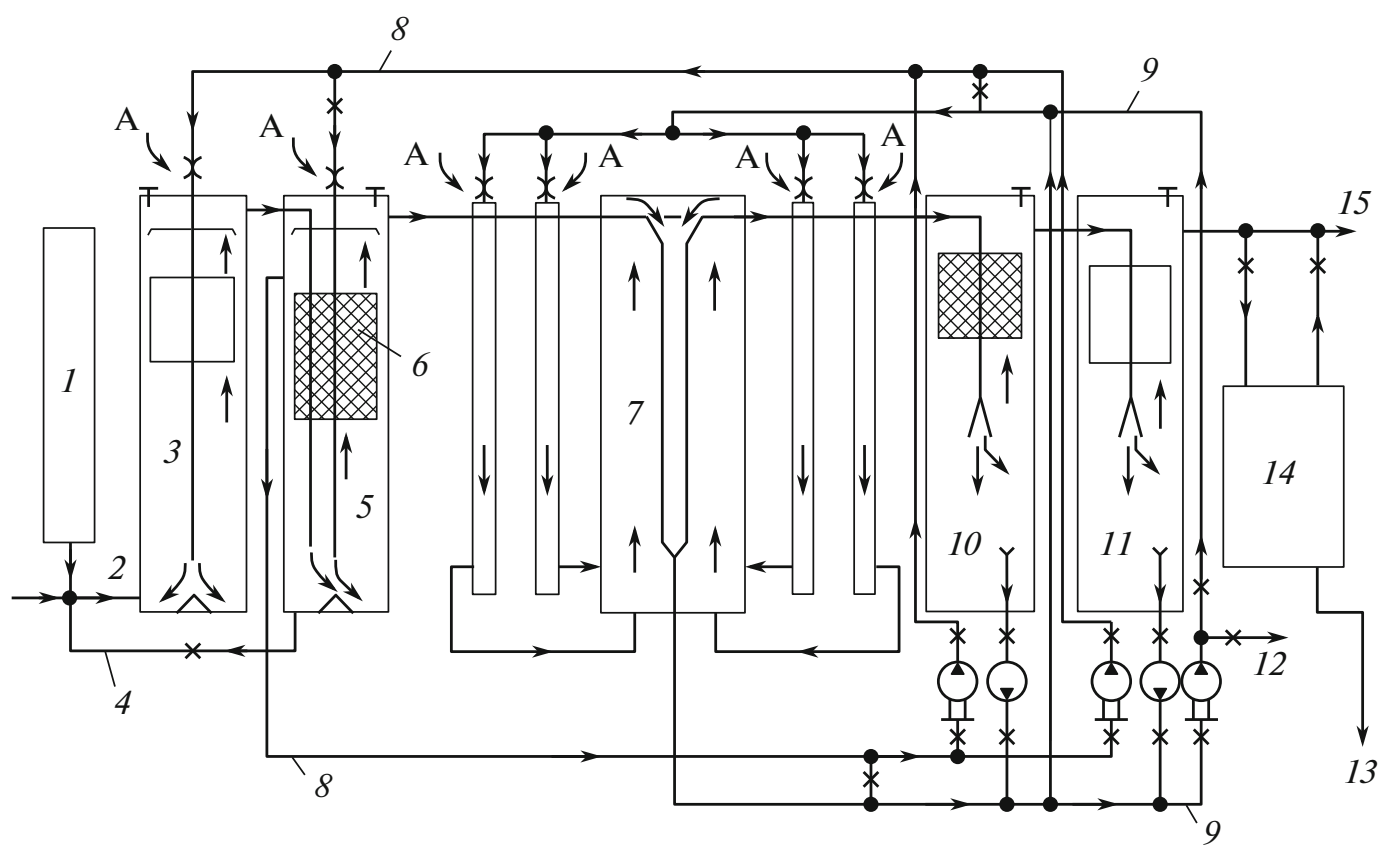

Designations: $*$, ejector; $\times$, flapper; $\quad \mathrm{T}$, breather valve; $\bigcirc$ A, turbojet pump; $\mathrm{A}$, air

Fig. 1. Scheme of the wastewater and sludge treatment: 1 , mechanical treatment; 2, input; 3, balancing tank; 4, emergency discharge; 5 , bioreactor; 6 , active sludge; 7, aerobic stabilizer; 8 , water-air mixture; 9, excessive (return) sludge; 10, sedimentation basin; 11, sedimentation basin; 12, sludge discharge; 13, to the reservoir; 14, advanced treatment, filtration, disinfection; 15, water discharge.

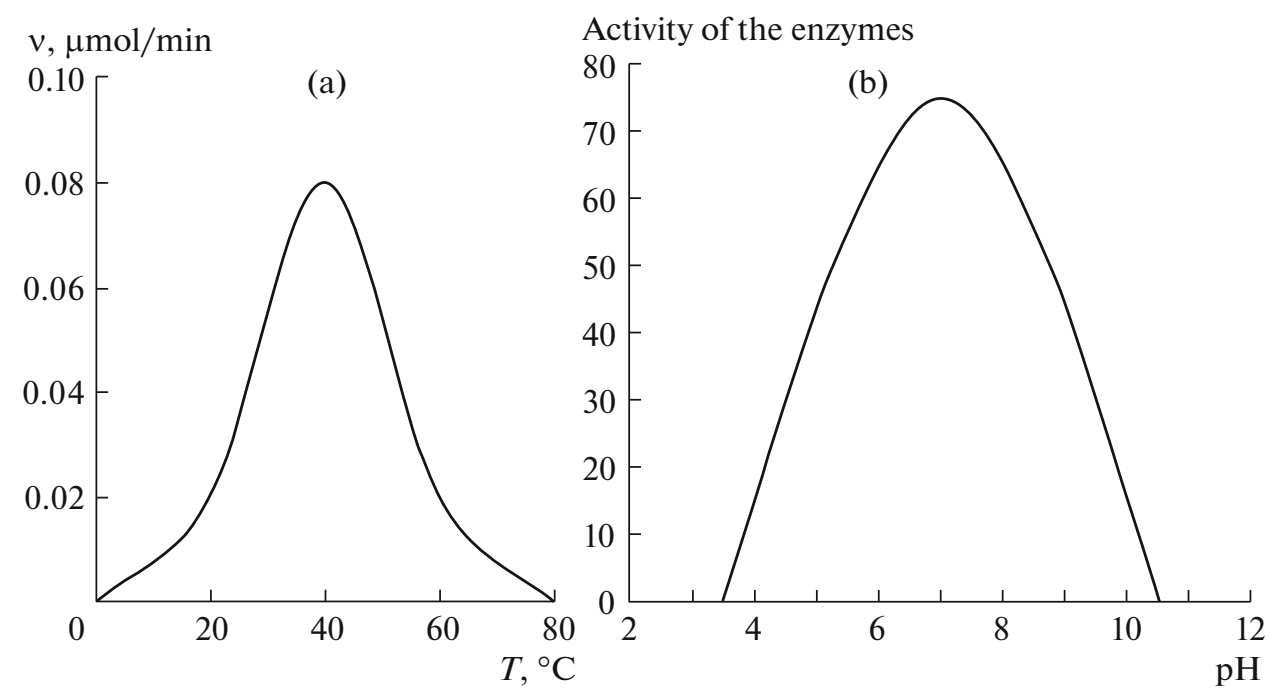

Fig. 2. Activity of the enzymes: (a) depending on the temperature; (b) depending on the medium $\mathrm{pH}$.

treat (on the nanolevel) the sludge. The activity and efficiency of the enzymes depends on the temperature of the medium and the $\mathrm{pH}$ of its hydrogen value.

It is also known $[2,3]$ that, for the biological treatment of wastewater, the mesophilic process is optimal and flows in the temperature range of $10-42^{\circ} \mathrm{C}$. Based on the J. Maxwell law of the distribution of the molecule velocities, the probability of achieving the maximum velocity can be expressed as $v_{0}=\sqrt{2(k T) / m}$, where $k$ is the Boltzmann constant, $T$ is the absolute temperature, and $m$ is the molecular mass. 


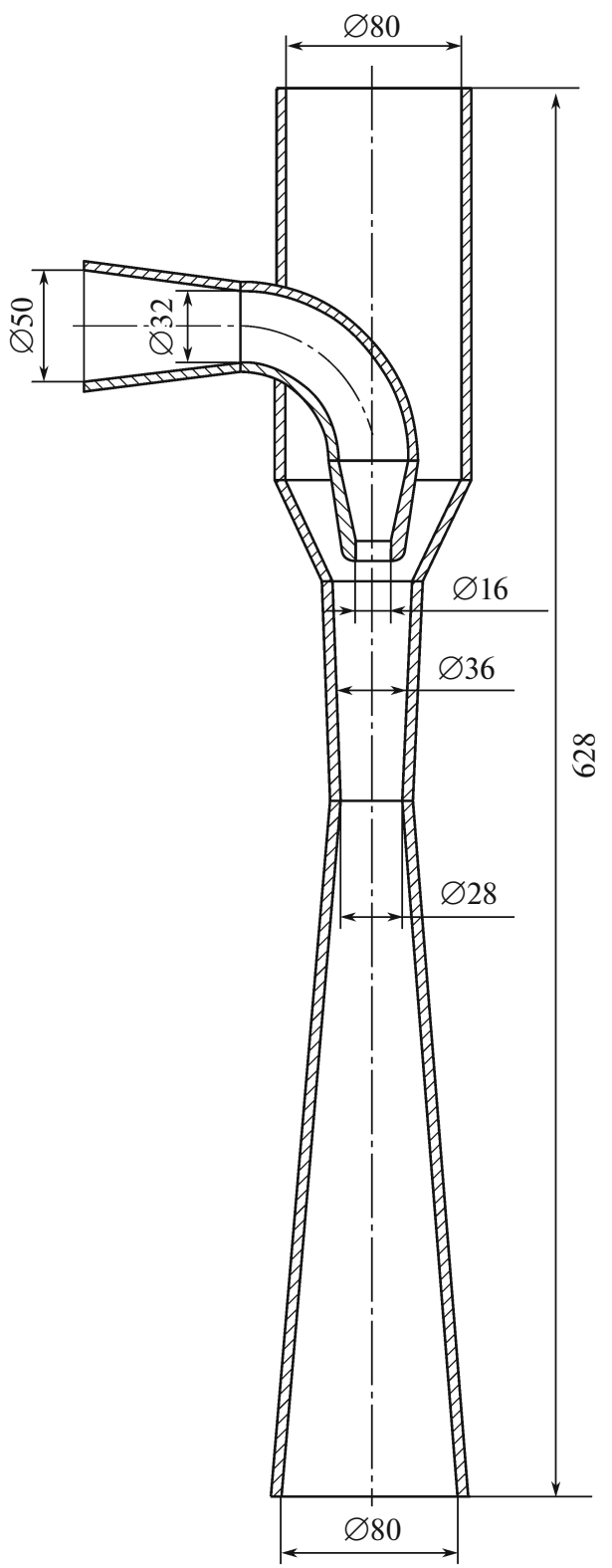

Fig. 3. Ejector (oxyjet) of the plants while treating the waste.

It follows that, at constant values $k$ and $m$, the velocity of the molecules (and substrate) is a function of the temperature. Studies have shown that, in the specified temperature range, the velocity of the molecules $v_{0}$ grows by $5.5 \%$, and the kinetic energy of the molecules increases by $11.1 \%$. This means that, beginning from temperature $T=10^{\circ} \mathrm{C}$, the self-heating of the treated substrate takes place. The enzymes contribute to the creation of a temperature that is comfortable to them.

According to [8], at temperatures $T \leq 0^{\circ} \mathrm{C}$ and $\geq 80^{\circ} \mathrm{C}$, the enzymes do not demonstrate any vital activity signs, and their maximum activity is fixed at $T \approx 40^{\circ} \mathrm{C}(\mathrm{Fig} .2 \mathrm{a})$, i.e., in the temperature range of the mesophilic process. The measurements show that, while implementing the enzymatic-cavitation method (at least in the middle latitudes), the temperature in the bioreactors is automatically supported in the range of $35-45^{\circ} \mathrm{C}$ (after the system achieves the predetermined conditions).

The enzymes are very sensitive to the medium acidity (Fig. 2b); the maximum activity of the enzymes is fixed at $\mathrm{pH}=7$ [8], which makes this a neutral medium. In the sludge treated and dried to a humidity of $35 \%$, the index $\mathrm{pH}=6.7$; i.e., it is near the optimum. The main function of energy conservation in the pants is fulfilled by the ejectors (oxyjets), which are simple jet devices that do not have any moving ele- 


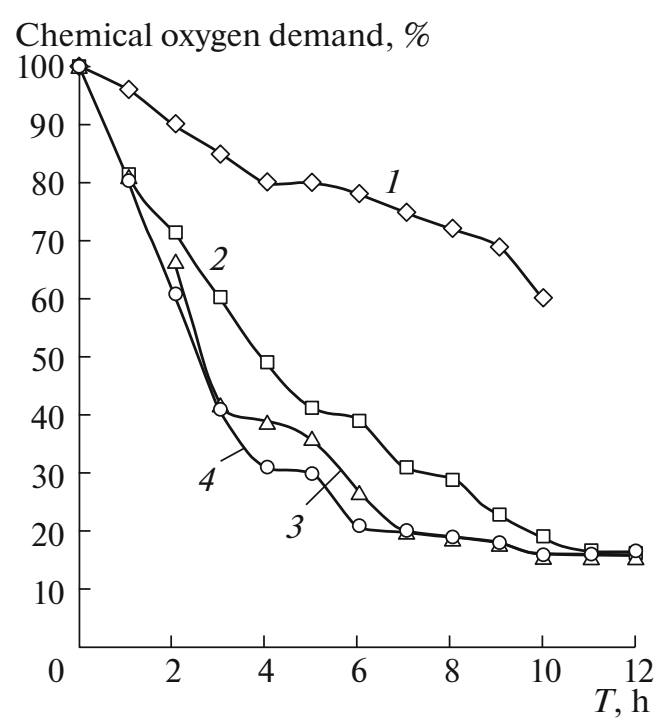

Fig. 4. Change of the COD depending on the pressure and treatment time: $1,0.20 ; 2,0.25 ; 3,0.30 ; 4,0.35 \mathrm{MPa}$.

ments; their design peculiarities in the structure of the plants are shown in Fig. 3. The flow pulse in any section of the jet device can be found using the expression $j=G V+p A$, where $G$ is the mass rate, $\mathrm{kg} / \mathrm{s}$; $v$ is the flow velocity, $\mathrm{m} / \mathrm{s} ; p$ is the medium pressure, $\mathrm{Pa}$; and $A$ is the flow section area, $\mathrm{m}^{2}$.

To define the capabilities of ejectors, let us use the results of the equation of the incompressible flow continuity, i.e., the ratio of the velocities $\left(v_{1}, v_{2}\right)$ and the cross-section area of the flow $\left(A_{1}, A_{2}\right)$ : $\mathrm{V}_{1} / \mathrm{v}_{2}=A_{2} / A_{1}$.

According to the calculations, due to the contraction in the vertical (hydraulic) pipeline, the flow velocity (ratio $v_{1}, v_{2}$ ) in the device (Fig. 3) increases by almost five times. As is known, the kinetic energy is proportional to the square of the velocities and increases by almost 25 times. The air from the atmosphere is supplied by a curved branch pipe carried by a hydraulic flow and, along with a substrate, discharged to the bioreactor. In this variant, the energy consumption of the plant is reduced by more than six times. Commercial methods of wastewater treatment (see, e.g., [9]) do not solve the problem of energy efficiency.

However, devices for wave gas-in-liquid dispersion have already been developed that do not use a compressor [10-12], et al., which may have prospective use in the systems of the wastewater biological treatment. The splitting of the gas flow into the bubbles has been carried out due to the pressure pulses created by the liquid waves that spread from the hydrodynamic oscillation generator. The average diameter of the gas bubbles on the optimal modes of the wave disperser makes $0.3-0.8 \mathrm{~mm}$ depending on the required gas consumption, which is commensurate with the author's observations while using the jet ejector.

According to the enzymatic-cavitation method, the quality and duration of the sludge treatment (reprocessing) depend significantly on the substrate pressure at the input to the ejectors. The flow pressure $p$ was varied at the input of the existing plant in the range of $0.20-0.35 \mathrm{MPa}$ (Fig. 4). The criterion for the quality of sludge treatment was the decrease in the chemical oxygen demand (COD) index to this value, which becomes constant; this in turn is an indication of the termination of the process.

The initial value $\mathrm{COD} \approx 100 \%$ proves that the organics in the substrate is strongly connected with other components; the sludge is not treated and the enzymes do not work. The sludge treatment process is finished when the COD index (and the organics amount) becomes stable and reaches $\approx 16 \%$ (after drying to the humidity $35-45 \%)$. This is achieved at $p=0.30-0.35 \mathrm{MPa}$ after $8 \mathrm{~h}$ of treatment. The process is also implemented at $p=0.25 \mathrm{MPa}$, but the time of treatment increases to 11 hours; $p<0.25 \mathrm{MPa}$ is unacceptable (Fig. 4).

After treating the sludge, the organic substance becomes nanostructured and easily accessible to the plant roots and soil biota (in the case when it is applied to the soil as a fertilizer). The treated sludge has significant adsorptive properties and is capable of accumulating moisture and air from the atmosphere. In this sludge there are general forms (also accessible) of nitrogen $(2.5 \%)$, phosphorus (4.2\%) and 
potassium (1.2\%), as well as mobile sulfur (up to $2 \mathrm{~g} / \mathrm{kg}$ ), which is the most important and critical supply source for plants [4].

Foreign specialists point to [12] the negative global consequences of the land use, which include the global accumulation of the production waste. The enzymatic-cavitation method allows one to solve not only the problems of liquidating organic-containing waste, but also obtaining efficient fertilizers and ameliorants when conserving energy resources. It is preferable to apply the method at some facilities to limit the volume of waste.

\section{REFERENCES}

1. Turovskii, I.S., Obrabotka osadkov stochnykh vod (Processing of Wastewater Depositions), Moscow: Stroiizdat, 1988.

2. Yakovlev, S.V. and Karyukhina, T.A., Biologicheskie protsessy v ochistke stochnykh vod (Biological Processes at Wastewater Treatment), Moscow: Stroiizdat, 1981.

3. Yakovlev, S.V. and Voronov, Yu.V., Vodootvedenie i ochistka stochnykh vod (Water Discharge and Waste Water Treatment), Moscow: Izd. ASV, 2004.

4. Pyndak, V.I., Novikov, A.E., and Stepkina, Yu.A., The way to solve a problem on wastes and degraded soils fertility. By an example of Lower Volga Region, Nauchn. Obozren., 2013, no. 4, pp. 85-89.

5. Pyndak, V.I. and Stepkina, Yu.A., Bioengineering machinery manufacturing: problems and trends. By an example of discharges processing, Probl. Mashinostr. Avtomatiz., 2013, no. 4, pp. 44-47.

6. Pyndak, V.I., Stepkina, Yu.A., and Stepkin, A.A., Grounding of ferment-cavitation method for processing domestic wastewater with producing meliorating fertilizers, Izv. Nizhnevolzhsk. Agrouniversitet. Kompleksa, 2013, no. 3, pp. $183-189$.

7. Pyndak, V.I., Chernova, Yu.A., Novikov, A.E., and Dugin, E.A., The way to modernize and decrease energy capacity of waste water processing stations, Remont. Vosstanovlen. Moderniz., 2016, no. 6, pp. 27-29.

8. Filippovich, Yu.B., Kovalevskaya, N.I., et al., Biologicheskaya khimiya: ucheb. posobie (Biological Chemistry. Student's Book), Kovalevskaya, N.I., Ed., Moscow: Akademiya, 2009.

9. Zhmur, N.S., Tekhnologicheskie i biokhimicheskie protsessy ochistki stochnykh vod na sooruzheniyakh s aerotenkami (Technological and Biochemical Processes for Wastewater Treatment for Buildings with Aerotanks), Moscow: Akvaros, 2003.

10. Ganiev, R.F., Zhebynev, D.A., and Korneev, A.S., Wavelike gas dispersion in a liquid in a compressor-free environment, J. Mach. Manuf. Reliab., 2009, vol. 38, no. 5, p. 485.

11. Ganiev, R.F., Zhebynev, D.A., Korneev, A.S., and Ukrainskii, L.E., Experimental study of wave gas dispersers in liquid, J. Mach. Manuf. Reliab., 2007, vol. 36, no. 6, p. 580.

12. Ganiev, R.F., Zhebynev, D.A., Korneev, A.S., and Ukrainskii, L.E., Wave dispersion effect for gas in liquid, Doklady Akadem. Nauk, 2007, vol. 416, no. 3, pp. 329-331.

13. Foley, J.A., De Fries, R., Asner, G.P., et al., Global consequences of land use, Science, 2005, vol. 309, no. 5734, pp. 570-574.

Translated by Yu. Bezlepkina 


\section{Contents}

\section{Journal of Machinery Manufacture and Reliability}

\section{Vol. 46, No. 5, 2017}

A simultaneous English language translation of this journal is available from Pleiades Publishing, Ltd.

Distributed worldwide by Springer. Journal of Machinery Manufacture and Reliability ISSN 1052-6188.

\section{Mechanics of Machines}

Development of Parallel-Structure Mechanisms with Four Degrees of Freedom and Four Kinematic Chains

\section{A. Glazunov and V. A. Borisov p. $417 \underline{\text { abstract }}$}

On the Rational Dynamic Modes of Vibrating Machines with an Unbalanced Vibration Exciter of Limited Power

A. E. Shokhin and A. N. Nikiforov p. 426 abstract

Integral Principle in the Problems of Dynamic Analysis of Gearshift in Automatic Gearboxes

K. B. Salamandra and L. I. Tyves p. 434 abstract

On the Effect of Ambient Pressure on the Bending of a Plate

M. A. Il'gamov p. 442 abstract

Parameter for Evaluation of the Layout Arrangement of the Metalworking Machines with Parallel Kinematics

E. B. Shchelkunov, S. V. Vinogradov, M. E. Shchelkunova, A. I. Pronin and V. V. Myl'nikov p. 448 abstract

A Comprehensive Approach to the Structural Synthesis and Evaluation of Engineering Solutions in the Design of Transportation and Technological Systems

A. Bardenhagen, L. V. Gavrilina, B. M. Klimenko, M. A. Pecheykina, D. L. Rakov and I. N. Statnikov p. 453 abstract 


\section{Reliability, Strength, and Wear Resistance of Machines and Structures}

Evaluation of Loading Dynamics and Fatigue Life for a Forwarder Half-Frame Articulation

S. A. Golyakevich and A. R. Goronovskii p. 463 abstract

Safety and Strength Coefficients of Mechanical Structures

N. A. Bilyk p. 472 abstract

Design Algorithm of Rational Fiber Trajectories in Arbitrarily Loaded Composite Plate

A. V. Malakhov and A. N. Polilov p. 479 abstract

Operational Damage to the Structure and Failure of the KAMAZ Truck Spring in the Temperature-Load Conditions of the North

S. P. Yakovleva, I. I. Buslaeva, S. N. Makharova and A. I. Levin p. 488 abstract

Procedure for Designing an Unloading Device for the Thrust Bearing of the Rotor of a Turbomachine

S. V. Faleev and A. S. Vinogradov p. 494 abstract

\section{New Technologies in Manufacturing}

Composite-Friendly Approach to Certification of Advanced Materials and Fabrication Methods used in Aviation Industry

S. V. Dubinskii and A. A. Safonov p. $\mathbf{5 0 1} \underline{\text { abstract }}$

Optimization of Organic-Containing Wastewater and Sludge Treatment Systems

V. I. Pyndak, A. E. Novikov and V. N. Shtepa p. 507 abstract

\section{Automation and Control in Machine Building}

Energy-Efficient Algorithm of Control of Exoskeleton Verticalization 
S. I. Savin, A. S. Yatsun and S. F. Yatsun p. 512 abstract

Pleiades Publishing home page $\mid$ journal home page $\mid$ top

If you have any problems with this server, contact webmaster. 